\title{
GUTENBERG'S BIBLE TO ZUCKERBERG'S FACEBOOK - THE CHANGING DYNAMICS OF SHARING INFORMATION
}

\section{Dr. BHARGAVI D HEMMIGE}

Associate Professor, Department of Media Studies, Jain University, Bengaluru, Karnataka, India

This paper examines the importance of inventions in Mass Media which changed the thought process of nations and in particular the invention of 'Movable Types' by German printer Johann Gutenberg, which altered the narrative of European society. Gutenberg's invention was selected by Time-Life magazine as the most important invention in the second millennium in 1997, and also he topped the list released by A\&E Network on the "People of the Millennium" and in "1,000 Years, 1,000 People: Ranking the Men and Women Who Shaped the Millennium" authored by American journalists-Agnes Hooper Gottlieb, Brent Bowers, Henry Gottlieb, Barbara Bowers. The Catholic Encyclopedia reiterates the importance of his invention and describes it as having made "unparalleled" cultural impact in the Christian era. Furthermore the paper discusses on the other inventions and the consequences of the same.
\end{abstract}

KEYWORDS: Mass Media, Movable Types, Printer \& Millennium

Received: Apr 18, 2019; Accepted: May 08, 2019; Published: Jun 12, 2019; Paper Id.: IJCMSJUN201920

\section{INTRODUCTION}

It is only appropriate to acknowledge the German goldsmith, who invented the mechanical movable type printing press, possibly the greatest invention of the modern age for it greatly impacted the dissemination of knowledge. The Bible, also known as the 42-line Bible, the Mazarin Bible or the B42, was one of the first significant books published with mass-produced removable metal type printed by him. It marked the beginning of the "Gutenberg Revolution" along with also the era of published publications in the West.

According to Hemming Nelson, former researcher, and Journalist at 'The Washington Post', "Gutenberg's innovation was a very simple device, but it established a revolution marked with continued improvements in engineering and, consequently, a popularization of their ideals of freedom and freedom of data exchange". Until then, as we're aware books were costly and therefore handwritten. John Gutenberg's invention of the printing press revolutionized bookmaking and its distribution around the world. As Aristotle, Politics states "Speech is the only reason we are "political animals", and this inventor needs to be revered for to then, now and all times to come.

Elizabeth Eisenstein in her book The Printing Press as an Agent of Change (1979)", argues, though printing had been in existence for centuries dating back to the Tang dynasty, there was no method to facilitate "mass-production of books", until Gutenberg's invention. The main contribution or impact of this movable printing press on European society was the spread of ideas which in turn gave birth to new theories, philosophies and ideas which led the people question the establishments, heralding the "Age of Enlightenment" which led to the Birth of Renaissance movement. Eisenstein further records in her book Divine Art, Infernal Machine (2010), “.... For from its early days some as magic is seen that the media. For the most part, nevertheless, it had been welcomed as a "divine art" by Western churchmen and statesmen". This American historian's work on the history of early printing 
and its effects on the social, political or cultural dimensions in early-modern Europe is unarguably the best documentation of the evolution of this greatest invention which was on big step towards today's global village.

\section{Luther's 95 Theses and Milton's Areopagatica, The Rise of Free Speech; Poet as a Writer of Political Prose}

The first public demonstration of the supremacy of the printing press came with Martin Luther's (1517) 95Theses, a powerful critical discourse on the Roman Catholic Church for its exploitations of authority. One of the key contributors to the rise of Lutheranism was the distribution of Luther's 95theses extensively in Europe. John Milton printed "Areopagitica," his controversial document against censorship, in 1644. He stands out for advocating the freedom of the press. "Truth," Milton wrote, "needs no licensing to make her victorious." His treatise titled "For the Liberty of Unlicenc'd Printing" to the Parliament of England in 1644 vehemently opposing licensing and censorship. This was because 1641 to 1643 saw the rise of numerous publications on the church, specifically protestant ideology which made the British Parliament come up with Licensing Order of 1643, in which the parliament required authors to have a license pre-approved by the government before their work could be published. Milton who was a victim himself distributed his written speech via pamphlet thus defying the censorship. Areopagitica turned out to be one of the most influential defenses of Right to Freedom of Speech and Expression, forming the basis to Bill of Rights both in England and USA. To quote him “...books aren't absolutely dead things, but do contain a potency of life to be able to become as active as that soul was whose progeny they are; nevertheless they do preserve as in a vial the purest efficacy and extraction of that living intellect that bred them. I know they are as lively, and as vigorously productive, as those fabulous dragon's teeth and being shown up and down, may chance to spring up armed men. And on the other hand, unless wariness be used, as good almost kill a man as kill a Fantastic book: who kills a man kills a reasonable creature, God's image; but he who destroys a Fantastic book, kills reason itself, kills the image of God, as it were, at the eye". Milton further thought of bound books as though they were living, breathing creatures and that to censor, restrict, or "license them is like killing a man. Furthermore, they encapsulate the "seasoned life of man" by containing the thoughts and desires of the man who wrote them as well those of the man or woman who reads them. His tagline was "The power to license is, of course, the power to deny a license".

Other notable contributions were of James Mill in England and Benjamin Constant in France who wrote at the time Principles of Politics Applicable to All Governments (1815). Thomas Jefferson in his letter written from Paris to Edward Carrington, the representative to the state of Virginia, he believes the part of a free media in maintaining government power in check is so important he would prefer "papers without government" into "government without papers".

\section{Media and Global Village}

Now if we map the evolution of mass communication from Gutenberg to Zuckerberg, we have to acknowledge Marshall McLuhan the Canadian professor who laid the cornerstones for the understanding of media theories.

McLuhan likened the vast network of communications systems to one extended central nervous system, ultimately linking everyone in the world, and coined the phrase 'Global Village' in the 1960s. He envisaged the vast power of Mass Media and insisted that ' Medium is the message'. When he made this statement first in 1958, at a Vancouver conference and wrote about it in his book "Understanding Media: The extensions of man 1964", he was subjected to unnecessary criticism. He argued that there would be a day when media channels would consume us. Today, in hindsight if we read his thought process we cannot agree more. The new media has totally consumed us in totality, from the way we 
book a ticket or travel, eat, communicate, entertain; media has indeed become the extension of our body and being.

As Claude Elwood Shannon, American mathematician and electrical engineer called "the father of information theory " endorsing McLuhan views in an interview to Omni Magazine in 1987 said he visualized a time when the people will be to robots what dogs are to humans under the influence of communication channels. That time has indeed arrived.

Marshall McLuhan commented that 'Gutenberg made everyone a reader. Xerox made everyone a publisher' - today we can update this quote by adding Facebook and Twitter has made everyone a journalist.

Here is an attempt to critically examine this journey from the time of Johan Gutenberg to Mark Zuckerburg and understand some of the key challenges and concerns laid down in the pathway. The mass media growth in the backdrop of globalisation and the all-pervasive role the media and communications are playing in our society with respect to democracy, social, political and cultural needs, are the focus of this keynote.

The eighteen century was swept by the popularity of the press and nineteen century saw the birth and evolution of telegraph which heralded a new form of dissemination of information and was used extensively by newspapers and news agencies.

The Info Age finally started to substitute the ideals of this industrial era. In 1983 Time Magazine called the PC the initial "Machine of the Year" Over a decade PCs outsold televisions. It meant we the masses, since the man of the year for its usage of technology. I am sure all of us read papers and watch TV and listen to the radio. We get information at the click of a button. Even the illiterate masses can see and understand the news, views sitting in the comfort of their homes at negligible cost son. And coming into the world wide web, it's altered the way we operate, how we get in touch with other people, our accessibility to advice, amidst the privacy issues". Social networking has also had and has a big influence in social movements Throughout the World in recent years by providing the average individual with the voice and confidence. The recent one worth mentioning is \#MeTOO movement which bought together all the women victims of sexual harassment.

\section{Media and Globalisation}

If we start wondering the dynamics of media economics how is this all possible, who is responsible for giving us this subsidized content and for what? How is it possible to deliver the newspaper and magazine at a subsidized rate? All roads lead to one answer that is Globalization. All this is done because of the patronage the mass media is receiving in the hands of multi-nationals and transnationals.

\section{Grossly Subsidised Media}

"We are not in the newspaper business, we are in the advertising business," Vineet Jain, the managing director of Bennett, Coleman \& Company Ltd (BCCL) is quoted as saying by The New Yorker, on Oct 8th 2012, while dwelling on the dominance of his company in the media business in India. BCCL, which owns The Times of India Group of newspapers, is a dominant player in the media business in India because it is very advertisement savvy. "If ninety per cent of your revenues come from advertising, you're in the advertising business," Jain says. We all know that he was blatantly frank enough to admit about the state of Times of India, which was started in 1838. And also this sums up the state of media in general too. 
There is no doubt that the existence and growth of mass media are directly related to globalization. If we recall the days prior to liberalization, privatization and globalization, how many channels did we have in our broadcast media? How was the quality of Newspapers? How did we access and share information? The convergence of broadband and television Technologies

Has opened new opportunities for the stream of media articles. As US-led Western media conglomerates have regionalized and localized their own content., they have extended their reach to all communities and regions in short, spread all over the world. In short world is their market.

The fascinating story is that of the mobile technology, The story of Google, Facebook, The role of advertisement, In short the impact of globalization per say can be summarized by this quote from Tom Goodwin of Havas, (French Media) "The world's biggest cab company, Uber, possesses no cars. The world's most well-known media firm, Facebook, generates no content. The planet's most precious merchant, Alibaba, conveys no inventory. Along with also the world's largest lodging provider, Airbnb, possesses no real estate".

The Rise of the Cyberspace : Access, Availability and Affordability

These are the 3 key pointers of the Internet that are the unlimited access, availability and affordability which makes interaction possible. Here are some of the studies by different authors on this phenomenon called social media From the 1980s,'cyberspace' -- the expression coined from the novelist William Gibson to explain the digital universe behind the monitor (1984) has been an odd distance. It was basically a geek conserve, using a social ethos which has been communal, libertarian, collaborative, sometimes raucous, anti-establishment and full of discussion and debate.

The web is a huge "network of networks", a network infrastructure that links millions of computers together globally, forming a network where any computer can communicate with one another, provided they're connected to the net. Furthermore, these computer networks are one of the modern technology platforms that assist people to communicate irrespective of distance or location in the world. It has turned the world into one big network that makes things happen within the shortest possible time. It has drawn the attention of all and sundry, young adolescents, and adults to establish platforms of interaction, sharing of experiences with colleagues, friends, associates and business partners. We media researchers classify it as New Media.

Social Networking is Known as "social" since it empowers communication, facilitates societal Create and interaction alliance, allows exchange and the production That generated material (Bryer and Zavatarro; 2011; Kaplan and Haenlein, 2010; King, 2012; O'Reilly, 2007)

The Media Researchers unanimously agree that the Effects of Social Media depend Large on the Degree of Usage, now let us see the Usage Pattern.

\section{So, how big is this Medium called the Internet in our Country?}

Net consumers will be 40 percent will be girls by 2020 and rural The Boston Consulting Group explained. "We estimate this India will have over 850 million users by 2025 United population of the G7 states," BCG stated in its report on 'Decoding Digital Consumers'. 


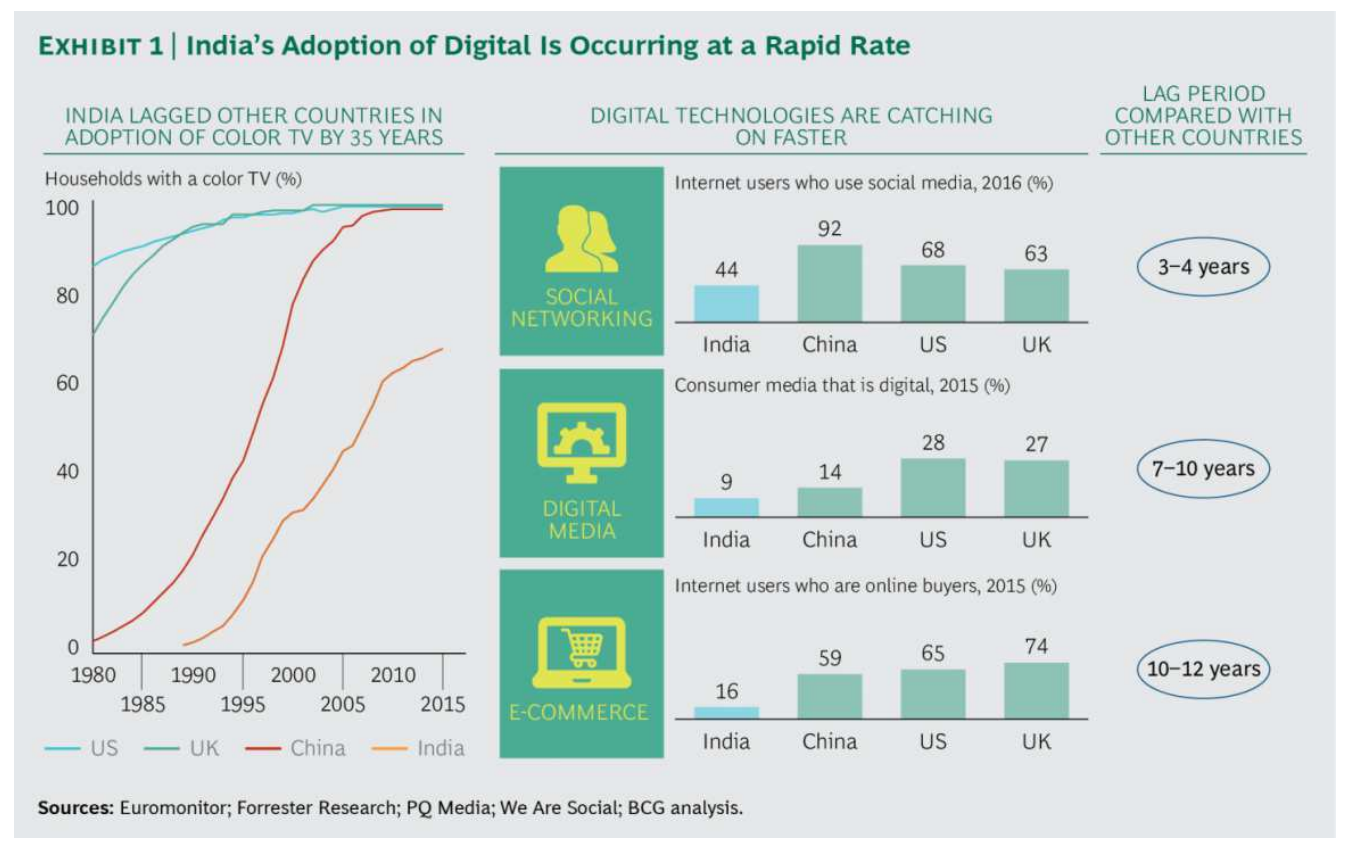

Figure 1

Another Study by Performed by The net and Mobile Association of India performed in May 2017, stated "Rural India is Getting a significant part online development. There have been an estimated 269163 million net users. Along with the hottest social networks in Facebook is estimated to reach near 319 million consumers in India by 2021, the Internet and Mobile Association of India he added."Affordability of mobile internet has been the primary factor for the popularity of the service so much so that internet penetration in India is being driven by mobile internet," said a report titled "Mobile Internet in India 2017', thus indicating affordable smartphones and internet connectivity as key contributors for the rise.

This gives us a clear picture of how big the Social Media Community is and how deeply it can affect our life.

\section{Privacy Concerns and the Rise of Fake News}

Spread through Facebook and WhatsApp, have contributed to the lynching deaths of some 20 individuals in certain months back in India, according to a tally in a regional media home.

Indian governments Have scrambled to react however, awareness campaigns, people alarms and internet blackouts have experienced limited success in deterring the spread of info.

The WhatsApp was blamed for its "reckless and volatile Messages" being shared with its 200 million users - the organization's Guaranteed action. Ads were taken out by the Social Networking giant in Indian papers offering "simple hints" to sort truth from fiction on Its stage.

It is important that each one has to also take cognizance of disinformation and fake news which is creating a new challenge to the functioning of a healthy society. There is no doubt that the creation of digital infrastructure creates socially and economically empowered citizens. But at the same time, there are certain challenges to be addressed.

Are online Through their telephones. India was the market for smartphones in 2017. Internet penetration in rural areas, handsets coupled's price To the world wide web programs is bringing many customers With cheap info. Speaking at the first-ever 'India Mobile Congress 2018', Mukesh Ambani, Chairman, Reliance Industries, said that the Indian economy has grown unparalleled and in the next 10 years, "India will direct the fourth industrial revolution together with all the 
telecom and IT sector coming together to put the base of enabling 1.3 billion Indians. It is turnover will reach $\$ 7$ billion in the present \$ two plus a half trillion at which, the Indian telecom and IT sector will play an integral part in generating digital transformation. He said, Data is the brand new oxygen, fresh oil for 1.3 billion Indians. Our purpose is to offer smartphones to assist individuals to connect with the world wide web but also information at reasonable rates,' Ambani told the gathering.

\section{CONCLUSIONS}

Whether one is a practitioner of mass communication as a subject, profession or not, but definitely all are the users and consumers of mass media especially with social media. As McLuhan and Shannon predicted this media has indeed become the extension of our central nervous system, indeed the world has become a global village, $i$ would like to reiterate the statement that "With social media we all have become journalists" and let us all use this weapon (media) responsibly with caution and commitment and contribute to the nation-building.

\section{REFERENCES}

1. Keynote address by Dr Bhargavi D Hemmige, at the 87th Conference on Mass Communication jointly organized by International Multidisciplinary Research Foundation and Government of India at Mysore on the November 2nd and 3rd, 2018.

2. Baran, S. J. (2002). Introduction to mass communication: Media literacy and culture (2nd Ed.). New York: McGraw-Hill. Berger, A. A. (2002).

3. Mass comm murders: Five media theorists self-destruct. New York: Rowan \& Littlefield.

4. The Printing Revolution in Early Modern Europe by Elizabeth L. Eisenstein

5. Divine Art, Infernal Machine: The Reception of Printing in the West from First Impressions to the Sense of an Ending by Elizabeth L. Eisenstein

6. https://www.washingtonpost.com/archive/1998/02/11/a-history-of-newspaper-gutenbergs-press-started-arevolution/2e95875c-313e-4b5c-9807-8bcb031257ad/?noredirect=on\&utm_term=.7bead560e4f8[2]

7. Lewalski, Barbara K. Life of Milton. Blackwell Publishing, 2002.

8. https://www.luther.delen/95thesen.html[3]Blasi, Vincent."Milton's Areopagitica and the Modern First Amendment."Yale Law School. Mar. 1995.[13] Hill, Christopher. Milton and the English Revolution. New York: Viking, 1977.[19] Mill, John Stuart. On Liberty. Peterborough, Canada: Broadview Press, 1999.[26] Hayek, F. A. "The Use of Knowledge."

9. https://oll.libertyfund.org/pages/james-mills-political-writings

10. Bentham, Jeremy. Introduction to Principles of Morals and Legislation. 1780.

11. https://admin.fee.org/files/doclib/books0604.pdf

12. https://www.passeidireto.com/arquivo/24995060/benjamin-constant-principles-of-politics-applicable-to-all-governments1815-/16

13. https://founders.archives.gov/documents/Jefferson/01-11-02-0047

14. McLuhan, Marshall (1967-03-19). "McLuhan: Now The Medium Is The Massage". New York Times.

15. McCluhan, M. (1962). The Gutenberg galaxy: The making of typographic man. London: Routledge\& Paul. 
16. McCluhan, M. (1964). Understanding media: The extensions of man. New York: McGraw-Hill. McCluhan, M., \& Fiore, Q. (1967). The medium is the massage. New York: Random House. McCluhan, M. (1995). Essential McCluhan. Edited by E. McLuhan \& F. Zingrone. New York: B

17. https://epdf.tips/the-information-a-history-a-theory-a-flood.htmlhttps://techcrunch.com/2015/03/03/in-the-age-ofdisintermediation-the-battle-is-all-for-the-customer-interfacel

18. https://www.forbes.com/sites/oracle/2015/04/20/digital-disruption-its-not-what-you-think/\#5d6b89229e06

19. Hauben, Michael, and Ronda Hauben. 1997. Netizens: On the History and Impact of Usenet and the Internet. Los Alamos, NM: IEEE Computer Society Press.

20. Gibson, William. 1984. Neuromancer. New York: Ace.

21. Naughton, John. 2012. From Gutenberg to Zuckerberg: What You Really Need to Know about the Internet. London: Quercus.

22. Naughton, John. 2015. "The Rise of Ad-blocking Could Herald the End of the Free Internet." The Observer, September 27.

23. https://www.theguardian.com/commentisfree/2015/sep/27/ad-blocking-herald-end-of-free-internet-ios9-apple

24. Benkler, Yochai. 2007. The Wealth of Networks: How Social Production Transforms Markets and Freedom. New Haven, CT: Yale.

25. https://www.tandfonline.com/doi/full/10.1080/23738871.2016.1157619

26. http://hrmars.com/hrmars_papers/Profiles_of_Secondary_School_Students'_Use_of_Social_Media_and_their_Views_about_i ts_Outcomes_to_Learning.pdf

27. https://gadgets.ndtv.com/telecom/news/india-to-have-850-million-online-users-by-2025-boston-consulting-group-1729935

28. Sanders, J. (2003, January 19). Advertisers, the middle-aged dis youth with slang. The San Francisco Chronicle.( Lexis-Nexis database).

29. Schramm, W. (1963). Mass communications: A book of readings selected and edited by the director of the institute for communication research at Stanford University. Urbana, IL: University of Illinois Press.

30. Smith, B. L., Lasswell, H., \& Casey, R. D. (1946). Propaganda, communication, and public opinion.

31. https://www.bcg.com/en-in/publications/2017/globalization-consumer-products-decoding-digital-consumers-india.aspx

32. https://economictimes.indiatimes.com/industry/telecom/telecom-news/by-2020-india-should-be-fully-4g-ready-for-5g-mukeshambani/articleshow/66360562.cms 
